\title{
The DEA method in the evaluation of the effectiveness of the Special Economic Zones in Poland in 2014
}

\author{
MAŁGORZATA BŁACHUCIAK ${ }^{1}$
}

The Jagiellonian University in Kraków, Institute of Economics, Finance and Management

\begin{abstract}
The aim of the study is to examine the degree of effectiveness of the Special Economic Zones in Poland and to indicate the diversity in their operation. In addition, the author's intention was to identify the determinants of efficiency, taking into account the political and economic conditions in which the zones function and their geographical location. The study uses data included in the Information on the implementation of special economic zones available on website premier.gov.pl from 2015. The data available in the source material allowed for the analysis of year 2014 only. In order to determine the effectiveness of the zones, the DEA (Data Envelopment Analysis) method was used.
\end{abstract}

Paper type: research article

Keywords: data envelopment analysis, DEA, efficiency, Special Economic Zones, SEZ

\section{Introduction}

Special Economic Zones (SEZ) have been operating in Poland for over twenty years. During that time these zones have combined the needs of investors, by facilitating the activities and needs of the regions, creating new jobs and infrastructure development. There are currently 14 economic zones in Poland. They vary in terms of size, number of permits issued and the expenditures incurred for their operation. However, they all operate under the same conditions, variable domestic and foreign economic and political situation, are not subject to competition and are not profit-oriented. Nevertheless, the effects of the operation of these zones are varied. It becomes important, therefore, to check how each zone performs in comparison to others.

1 mblachuciak@gmail.com 
The aim of the study is to examine whether SEZs operating in Poland maintain a sufficient ratio of expenditure to results. For this purpose, the DEA (Data Envelopment Analysis) method was used. It allows for specifying the pattern, so that one can determine which units are effective and which are not. The method used allows for the comparison of units for which there is no information about all the possible combinations of expenditure and effects. The knowledge about the effectiveness of individual zones may contribute to better allocation of public funds among zones and selection of units in which processes or management methods should be improved.

\section{The formation and functioning of the Special Economic Zones in Poland}

One of the main reasons for the formation of Special Economic Zones was the need to reduce disparities between the levels of economic development of regions which grew as a result of the socio-economic and political transformation in 1989. The benefits resulting from investing in the zones aimed at attracting domestic and foreign investors who, investing capital in the zones, will contribute to increasing the competitiveness of Polish regions (Nelec \& Prusek, 2006; Kudełko, 2006).

The first piece of legislation giving rise to the creation of SEZ was the act of $20^{\text {th }}$ October 1994 on Special Economic Zones. It laid out that the zone is a separated, uninhabited part of the Polish territory, in the area of which business activity under the terms of that act may be conducted (Journal of Laws of 2007, no. 42, item 273).

In its first form the act stated that the companies authorized to operate in the area were completely exempt from income tax for the first 10 years, and then, by the end of the existence of the zone, the relief was 50\%. At the same time entrepreneurs were entitled to exemption from property tax (Golik \& Kątnik-Prokop, 2014, p. 181).

Since the establishment of zones, the rules of investing in them have been amended multiple times. Currently, the entrepreneur who receives a permit to operate in the zone can count on $15-50 \%$ relief from income tax. The amount of relief is dependent on the region/zone in which the entrepreneur operates. Small and medium-sized enterprises can, additionally, receive larger relief, respectively 20 and 10 percentage points (with the exception of large investment projects). In addition, the zones offer the use of developed land, the opportunity to purchase or lease the existing real estate, administrative support, as well as additional relief or exemption from property tax, usually offered to new entrepreneurs. ${ }^{2}$

2 Ordinance of the Council of Ministers of 12 November 2014 amending the regulation on state aid granted to entrepreneurs operating on the basis of a permit for conducting business activity in special economic zones (Journal of Laws of 2014, item 1755). 
At the end of 2014, in Poland there are 14 SEZs (Table 1).

Table 1 Location and area of special economic zones

\begin{tabular}{|c|c|c|c|c|c|}
\hline Zone name & Voivodeship & Ranking & Share (\%) & Area (ha) & $\begin{array}{l}\text { The degree of } \\
\text { land use (\%) }\end{array}$ \\
\hline Kamiennogórska & $\begin{array}{l}\text { dolnośląskie, wielkopol- } \\
\text { skie }\end{array}$ & 13 & 2.3 & 413.40 & 52.76 \\
\hline Katowicka & $\begin{array}{l}\text { śląskie, małopolskie, } \\
\text { opolskie }\end{array}$ & 2 & 12.9 & $2,347.34$ & 60.60 \\
\hline $\begin{array}{l}\text { Kostrzyńsko- } \\
\text { Słubicka }\end{array}$ & $\begin{array}{l}\text { lubuskie, wielkopolskie } \\
\text { zachodniopomorskie }\end{array}$ & 4 & 9.6 & $1,746.98$ & 63.19 \\
\hline Krakowska & $\begin{array}{l}\text { małopolskie, podkar- } \\
\text { packie }\end{array}$ & 11 & 3.9 & 707.78 & 74.24 \\
\hline Legnicka & dolnośląskie & 8 & 6.7 & $1,212.42$ & 26.06 \\
\hline Łódzka & $\begin{array}{l}\text { lódzkie, wielkopolskie, } \\
\text { mazowieckie }\end{array}$ & 7 & 7.2 & $1,302.26$ & 75.08 \\
\hline Mielecka & $\begin{array}{l}\text { podkarpackie, } \\
\text { małopolskie, lubelskie, } \\
\text { zachodniopomorskie }\end{array}$ & 6 & 7.5 & $1,362.99$ & 70.95 \\
\hline Pomorska & $\begin{array}{l}\text { pomorskie, kujawsko- } \\
\text { pomorskie, wielkopolskie, } \\
\text { zachodniopomorskie }\end{array}$ & 3 & 10.3 & $1,863.27$ & 64.71 \\
\hline Słupska & $\begin{array}{l}\text { pomorskie, zachodnio- } \\
\text { pomorskie }\end{array}$ & 10 & 4.5 & 816.79 & 35.05 \\
\hline Starachowicka & $\begin{array}{l}\text { świętokrzyskie, ma- } \\
\text { zowieckie, opolskie, } \\
\text { łódzkie, lubelskie } \\
\end{array}$ & 12 & 3.6 & 644.46 & 66.01 \\
\hline Suwalska & $\begin{array}{l}\text { podlaskie, warmińsko- } \\
\text { mazurskie, mazowieckie }\end{array}$ & 14 & 2.1 & 375.63 & 74.81 \\
\hline Tarnobrzeska & $\begin{array}{l}\text { podkarpackie, ma- } \\
\text { zowieckie, świętokrzyskie, } \\
\text { lubelskie, dolnośląskie, } \\
\text { podlaskie }\end{array}$ & 5 & 9.2 & $1,677.17$ & 68.84 \\
\hline Wałbrzyska & \begin{tabular}{|l} 
dolnośląskie, opolskie, \\
wielkopolskie, lubuskie
\end{tabular} & 1 & 14.6 & $2,648.59$ & 59.93 \\
\hline $\begin{array}{l}\text { Warmińsko- } \\
\text { Mazurska }\end{array}$ & $\begin{array}{l}\text { warmińsko-mazurskie, } \\
\text { mazowieckie }\end{array}$ & 9 & 5.6 & $1,014.88$ & 69.51 \\
\hline \multicolumn{2}{|l|}{ SUM } & & 100 & $18,133.97$ & 61.63 \\
\hline
\end{tabular}

Source: based on Information on the implementation of special economic zones in 2015. 
Zones vary in size and degree of development. The largest area is of the Wałbrzyska Zone (2,648.59 ha), of which almost $60 \%$ has already been developed. The smallest zone is the Suwalska Zone ( $375.63 \mathrm{ha}$ ), whose area is $86 \%$ smaller than in the case of the Wałbrzyska Zone. The lowest percentage of development is characteristic of the Legnicka Zone (26.06\%), the highest is in the Łódzka Zone (75.08\%).

One of the factors which may contribute to the attractiveness and also the potential of the zone is the number of permits issued to conduct business activity. In 2014, 436 entrepreneurs received such permits (Table 2). In comparison with 2013, the number of permits granted rose by $72.3 \%$.

Table 2 Number of valid permits issued

\begin{tabular}{|l|c|c|c|c|}
\hline \multicolumn{1}{|c|}{ Zone name } & $\mathbf{2 0 1 3}$ & $\mathbf{2 0 1 4}$ & $\begin{array}{c}\text { Cumulatively at } \\
\text { the end of 2014 }\end{array}$ & $\begin{array}{c}\text { Change } \\
\text { 2014/2013 (\%) }\end{array}$ \\
\hline Kamiennogórska & 10 & 7 & 61 & -30.0 \\
\hline Katowicka & 28 & 58 & 302 & 107.1 \\
\hline Kostrzyńsko-Słubicka & 19 & 34 & 164 & 78.9 \\
\hline Krakowska & 32 & 44 & 140 & 37.5 \\
\hline Legnicka & 10 & 19 & 81 & 90.0 \\
\hline Łódzka & 19 & 36 & 200 & 89.5 \\
\hline Mielecka & 25 & 42 & 207 & 68.0 \\
\hline Pomorska & 23 & 36 & 139 & 56.5 \\
\hline Słupska & 14 & 20 & 75 & 42.9 \\
\hline Starachowicka & 8 & 5 & 76 & -37.5 \\
\hline Suwalska & 11 & 16 & 81 & 45.5 \\
\hline Tarnobrzeska & 14 & 39 & 184 & 178.6 \\
\hline Wałbrzyska & 27 & 64 & 261 & 137.0 \\
\hline Warmińsko-Mazurska & 13 & 16 & 85 & 23.1 \\
\hline SUM & 253.00 & 436.00 & 2,056 & 72.3 \\
\hline
\end{tabular}

Source: based on Information on the implementation of special economic zones in 2015.

In 2014, most permits were issued in the zone of Wałbrzych (64), Katowice (58), Kraków (44), Mielec (42) and Tarnobrzeg (39). The last one recorded the highest growth rate in relation to the previous year. The Kamiennogórska (7) and Starachowicka (5) Zones in 2014 issued fewer permits than in the previous year.

From the beginning of the operation of zones, at the end of 2014, most of permits were obtained by entrepreneurs in the zone of Katowice (302), and then in the 
zone of Wałbrzych (261), Mielec (207), Łódź (200) and Tarnobrzeg (184). Businesses operating in the territory of the five zones mentioned acquired more than $56.1 \%$ of all valid permits. The total number of permits issued by the end of 2014 amounted to 3,211, but some of them have been revoked, discontinued or cancelled. Such situations occur in the event where the entrepreneur fails to meet the conditions of the permit, which usually refers to the condition of employment. In 2014 only, 45 permits were revoked (Information on the implementation of special economic zones, 2015, p. 13).

Entrepreneurs conducting business activity in the zones in 2014 spent 8,812.10 million in investment, which is $20.6 \%$ more than in the previous year (Table 3 ).

Table 3 Investment expenditures in SEZ (in million PLN)

\begin{tabular}{|l|r|r|r|c|}
\hline \multicolumn{1}{|c|}{ Zone name } & 2013 & 2014 & $\begin{array}{c}\text { Cumulatively at } \\
\text { the end of 2014 }\end{array}$ & $\begin{array}{c}\text { Change } \\
\text { 2014/2013 (\%) }\end{array}$ \\
\hline Kamiennogórska & 53.00 & 130.20 & $2,039.30$ & 145.7 \\
\hline Katowicka & $1,516.30$ & -12.40 & $21,097.1$ & -100.8 \\
\hline Kostrzyńsko-Słubicka & 593.10 & 548.20 & $5,860.3$ & -7.6 \\
\hline Krakowska & 178.10 & 397.70 & $2,362.1$ & 123.3 \\
\hline Legnicka & 818.60 & 831.90 & $7,134.3$ & 1.6 \\
\hline Łódzka & 835.30 & $1,652.40$ & $12,467.9$ & 97.8 \\
\hline Mielecka & 422.50 & 593.80 & $6,652.8$ & 40.5 \\
\hline Pomorska & 548.50 & $1,202.50$ & $9,064.7$ & 119.2 \\
\hline Słupska & 55.60 & 151.70 & $1,383.6$ & 172.8 \\
\hline Starachowicka & 103.60 & 142.10 & $1,886.9$ & 37.2 \\
\hline Suwalska & 26.60 & 137.00 & $1,745.2$ & 415.0 \\
\hline Tarnobrzeska & 212.50 & 376.90 & $7,952.4$ & 77.4 \\
\hline Wałbrzyska & $1,743.50$ & $2,276.30$ & $18,619.1$ & 30.6 \\
\hline Warmińsko-Mazurska & 200.80 & 383.80 & $3,687.6$ & 91.1 \\
\hline SUM & $7,308.00$ & $8,812.10$ & $101,953.30$ & 20.6 \\
\hline
\end{tabular}

Source: based on Information on the implementation of special economic zones in 2015.

The highest investment expenditures were incurred in the Wałbrzyska Zone, while the highest dynamics in comparison to the previous year was characteristic of the Suwalska Zone. A specific example is the zone of Katowice, where expenditures in 2014 gained a negative value. The reason for this situation is the withdrawal of the permit for one of the largest investors (Information on the implementation of special economic zones, 2015). 
Another positive effect of the operation of the zones is the creation of new jobs. In 2014213,939 new positions were created in all 14 zones (Table 4). It is $9.1 \%$ more compared to the previous year. The zone which created the majority of new jobs is the zone of Katowice, while the highest dynamics was characteristic of the zone of Kraków. The Starachowicka Zone was the only one where there was a decrease in the number of new jobs in relation to the previous year, and the Słupska Zone recorded the lowest number of new jobs.

Table 4 New jobs created in the SEZ in 2014

\begin{tabular}{|l|r|r|r|}
\hline \multicolumn{1}{|c|}{ Zone name } & 2013 & $\mathbf{2 0 1 4}$ & $\begin{array}{c}\text { Change } \\
\text { 2014/2013 (\%) }\end{array}$ \\
\hline Kamiennogórska & 4,622 & 5,508 & 19.2 \\
\hline Katowicka & 39,133 & 40,524 & 3.6 \\
\hline Kostrzyńsko-Słubicka & 15,062 & 16,929 & 12.4 \\
\hline Krakowska & 7,928 & 9,717 & 22.6 \\
\hline Legnicka & 9,983 & 11,319 & 13.4 \\
\hline Lódzka & 20,535 & 23,564 & 14.8 \\
\hline Mielecka & 19,731 & 20,585 & 4.3 \\
\hline Pomorska & 11,848 & 13,345 & 12.6 \\
\hline Słupska & 2,867 & 2,991 & 4.3 \\
\hline Starachowicka & 3,368 & 3,324 & -1.3 \\
\hline Suwalska & 5,170 & 5,941 & 14.9 \\
\hline Tarnobrzeska & 19,007 & 19,761 & 4.0 \\
\hline Wałbrzyska & 28,830 & 32,139 & 11.5 \\
\hline Warmińsko-Mazurska & 8,041 & 8,292 & 3.1 \\
\hline SUM & 196,125 & 213,939 & 9.1 \\
\hline
\end{tabular}

Source: based on Information on the implementation of special economic zones in 2015.

Special Economic Zones in addition to the land, of course, have managing authorities. They take care of the growth of the zones by developing infrastructure and promoting units to attract the greatest number of investors. The zones are usually managed by local governments or media managers.

In 2014, more than 390 million PLN was spent on infrastructure. And cumulatively, at the end of 2014 more than 3.5 billion PLN (Table 5). 


\begin{tabular}{|c|c|c|c|c|c|c|c|c|c|c|c|c|c|c|c|c|}
\hline \multicolumn{2}{|c|}{ 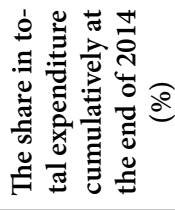 } & $\stackrel{0}{0}$ & $\stackrel{\circ}{\underset{I}{-}}$ & $\stackrel{0}{\infty}$ & in & $\stackrel{\infty}{-\infty}$ & $\ddot{n}$ & $\stackrel{\sim}{\vec{m}}$ & $\stackrel{+}{ \pm}$ & $\overrightarrow{+}$ & $\stackrel{+}{0}$ & $\hat{0}$ & $\stackrel{\bullet}{\circ}$ & 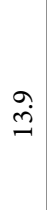 & के & 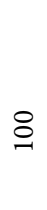 \\
\hline \multicolumn{2}{|c|}{ 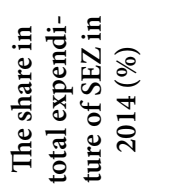 } & $\overrightarrow{0}$ & $\begin{array}{l}\stackrel{L}{\mathrm{I}} \\
\stackrel{\mathrm{N}}{2}\end{array}$ & $\stackrel{\circ}{+}$ & $\vec{b}$ & 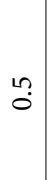 & $\stackrel{H}{m}$ & $\begin{array}{l}\stackrel{+}{0} \\
\stackrel{n}{n}\end{array}$ & $\stackrel{n}{=}$ & $\stackrel{\sim}{\sim}$ & $\stackrel{2}{0}$ & $\stackrel{n}{0}$ & $\stackrel{\overbrace{}}{\stackrel{2}{二}}$ & $\stackrel{\sim}{\underset{J}{*}}$ & $\stackrel{\sharp}{-}$ & 8 \\
\hline \multirow{3}{*}{ 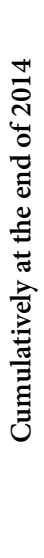 } & 氶 & $\stackrel{\ddot{H}}{\stackrel{H}{*}}$ & $\begin{array}{l}\stackrel{H}{d} \\
\text { S̊ } \\
\text { in }\end{array}$ & $\begin{array}{l}\text { N} \\
\infty \\
\infty \\
\sim\end{array}$ & $\begin{array}{l}\text { aे } \\
\text { aे }\end{array}$ & $\begin{array}{l}0 \\
\dot{b}\end{array}$ & $\begin{array}{l}\stackrel{n}{+} \\
\stackrel{m}{m}\end{array}$ & & $\begin{array}{l}\stackrel{\infty}{\sigma} \\
\stackrel{\vec{n}}{n}\end{array}$ & $\stackrel{g}{\exists}$ & $\widehat{\grave{\jmath}}$ & $\stackrel{g}{\underset{N}{*}}$ & $\begin{array}{l}\stackrel{\leftrightarrow}{0} \\
\stackrel{p}{m}\end{array}$ & $\begin{array}{l}\text { be } \\
\text { in }\end{array}$ & 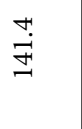 & $\begin{array}{l}8 \\
8 \\
\text { m }\end{array}$ \\
\hline & 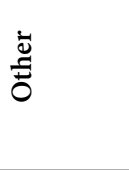 & $\stackrel{\leftrightarrow}{+}$ & $\begin{array}{l}2 \\
\text { bे } \\
\dot{q}\end{array}$ & Ә & 范 & $\begin{array}{l}+ \\
\infty \\
-\end{array}$ & $\begin{array}{l}\overrightarrow{0} \\
\dot{0} \\
i\end{array}$ & $\begin{array}{l}2 \\
\stackrel{\nu}{0} \\
\text { r. }\end{array}$ & $\stackrel{\infty}{i}$ & $\begin{array}{l}\stackrel{+}{\Delta} \\
\stackrel{\Xi}{J}\end{array}$ & $\vec{m}$ & 0 & $\begin{array}{c}\infty \\
\stackrel{1}{ } \\
\infty \\
-1\end{array}$ & $\begin{array}{l}0 \\
\text { in } \\
m\end{array}$ & $\begin{array}{l}\vec{b} \\
\stackrel{0}{0}\end{array}$ & $\begin{array}{l}\tilde{n} \\
\tilde{N} \\
\tilde{N} \\
\hat{i}\end{array}$ \\
\hline & 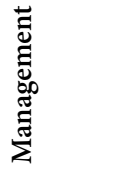 & $\stackrel{\infty}{-}$ & $\begin{array}{l}\stackrel{\mathscr{H}}{\mathrm{J}} \\
\mathrm{f}\end{array}$ & $\hat{\infty}$ & ఫे & $\underset{f}{\stackrel{f}{f}}$ & $\begin{array}{l}\stackrel{H}{a} \\
\infty \\
+\end{array}$ & $\begin{array}{l}\stackrel{\sim}{\tilde{N}} \\
\underset{\sim}{\Xi}\end{array}$ & $\stackrel{\infty}{\mathbb{H}}$ & $\begin{array}{l}0 \\
\stackrel{\sim}{\sim}\end{array}$ & $\stackrel{\circ}{\circ}$ & $\underset{\sim}{\stackrel{\sim}{N}}$ & $\begin{array}{l}\stackrel{2}{1} \\
\stackrel{2}{n}\end{array}$ & $\underset{J}{ \pm}$ & $\stackrel{m}{n}$ & 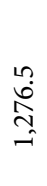 \\
\hline \multirow{3}{*}{$\frac{\pi}{\stackrel{d}{*}}$} & సేّํ & $\stackrel{m}{0}$ & $\frac{a}{\infty}$ & $\begin{array}{l}\text { in } \\
\text { in }\end{array}$ & $\stackrel{\infty}{\underset{\sim}{+}}$ & $\stackrel{9}{-}$ & $\begin{array}{l}\ddot{\oplus} \\
\stackrel{\sim}{二}\end{array}$ & 8 & $\underset{+}{\mathbb{Z}}$ & $\begin{array}{l}0 \\
\infty\end{array}$ & $\stackrel{\infty}{-}$ & $\stackrel{9}{-}$ & $\stackrel{n}{\hat{b}}$ & 苑 & 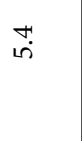 & 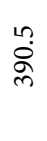 \\
\hline & 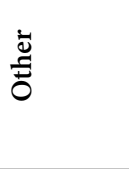 & 0 & $\stackrel{\sim}{\infty}$ & $\stackrel{\sim}{ \pm}$ & $\stackrel{\vartheta}{\sigma}$ & $\stackrel{\infty}{0}$ & $\stackrel{\Upsilon}{N}$ & $\begin{array}{l}\text { gे } \\
\text { in }\end{array}$ & $\stackrel{\widehat{\lrcorner}}{\mathrm{I}}$ & $\begin{array}{l}0 \\
\infty \\
\infty\end{array}$ & 0 & 0 & 窝 & $\begin{array}{l}\stackrel{a}{\infty} \\
\stackrel{\sim}{ }\end{array}$ & $\stackrel{H}{\text { in }}$ & $\begin{array}{l}\hat{i} \\
\text { I }\end{array}$ \\
\hline & 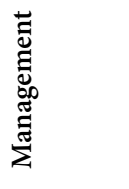 & ?ִ & ชู & $\stackrel{\infty}{0}$ & $\stackrel{a}{\Lambda}$ & $\exists$ & ชู & $\overrightarrow{0}$ & $\frac{+}{m}$ & 0 & $\stackrel{\infty}{-}$ & $\stackrel{9}{-}$ & $\begin{array}{l}\stackrel{0}{\Xi} \\
=\end{array}$ & $\begin{array}{l}n ! \\
\infty \\
\infty\end{array}$ & 0 & $\stackrel{\infty}{\text { ஸ́ }}$ \\
\hline \multicolumn{2}{|c|}{ 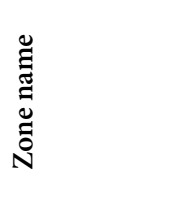 } & 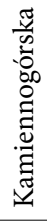 & 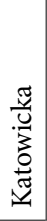 & 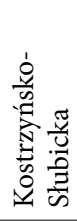 & 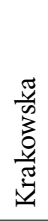 & 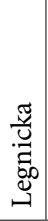 & 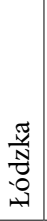 & 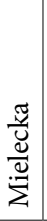 & 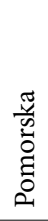 & $\begin{array}{l}\frac{\tilde{w}}{\omega} \\
\tilde{\Xi} \\
\tilde{\xi}\end{array}$ & 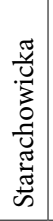 & 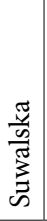 & 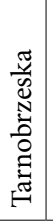 & 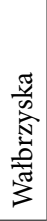 & 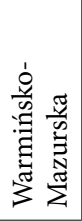 & $\sum_{\substack{S \\
\text { S }}}$ \\
\hline
\end{tabular}


The zone, in which in 2014 the largest amount of money was spent on infrastructure (management together with others, i.e. community, media managers and the General Directorate for National Roads and Highways) is the zone of Katowice. It is surprising that, cumulatively at the end of 2014, the expenses were the highest in the Pomorska Zone, not in the Wałbrzyska Zone which is the largest zone or the Katowicka Zone which issued the biggest number of permits for conducting business activity. The Pomorska Zone accounts for $14.4 \%$ of the cumulative expenditure and the Starachowicka Zone, with the smallest expenditure on infrastructure, accounts for only $0.4 \%$ of total expenditure at the end of 2014 (Table 5).

As mentioned, the management authorities of the zones must also take care of the promotion of their zones. Table 6 shows the expenses incurred for promotion in 2014 and cumulatively at the end of 2014.

Table 6 Expenditures for promotion (in million PLN) incurred by the companies managing the zones

\begin{tabular}{|l|c|c|c|c|}
\hline \multicolumn{1}{|c|}{ Zone name } & $\mathbf{2 0 1 4}$ & $\begin{array}{c}\text { Cumulatively at the } \\
\text { end of 2014 }\end{array}$ & $\begin{array}{c}\text { Share in expenditure } \\
\text { in 2014 (\%) }\end{array}$ & $\begin{array}{c}\text { Share in expenditure } \\
\text { cumulatively at the } \\
\text { end of 2014 (\%) }\end{array}$ \\
\hline Kamiennogórska & 0.15 & 1.29 & 1.9 & 1.8 \\
\hline Katowicka & 0.73 & 11.44 & 9.4 & 16.3 \\
\hline Kostrzyńsko-Słubicka & 1.24 & 10.96 & 16.0 & 15.7 \\
\hline Krakowska & 0.57 & 5.32 & 7.4 & 7.6 \\
\hline Legnicka & 0.14 & 3.05 & 1.8 & 4.4 \\
\hline Łódzka & 1.07 & 8.77 & 13.8 & 12.5 \\
\hline Mielecka & 0.15 & 2.64 & 1.9 & 3.8 \\
\hline Pomorska & 0.88 & 8.54 & 11.4 & 3.1 \\
\hline Słupska & 0.70 & 2.14 & 9.0 & 2.2 \\
\hline Starachowicka & 0.14 & 1.51 & 1.8 & 5.0 \\
\hline Suwalska & 0.25 & 3.49 & 3.2 & 3.6 \\
\hline Tarnobrzeska & 0.19 & 2.51 & 2.5 & 11.0 \\
\hline Wałbrzyska & 1.50 & 7.70 & 19.4 & 0.9 \\
\hline Warmińsko-Mazurska & 0.04 & 0.65 & 0.5 & 100 \\
\hline SUM & 7.75 & 70.01 & 100 & \\
\hline
\end{tabular}

Source: based on Information on the implementation of special economic zones in 2015.

The Kostrzyńsko-Słubicka Zone in 2014 spent the largest amount on promotion and, in total, since the beginning of its existence ranks the second place in terms of investment in this field. It is worth noting here that regarding the amount 
of valid permits issued, this zone comes in the $6^{\text {th }}$ place. The Warmińsko-Mazurska Zone both in 2014 and cumulatively at the end of 2014 spent the smallest amount for this purpose.

Under the current law, companies operating in the zones may benefit from exemption from income tax in the tax year or in the year following it for the purpose of the development of the zone, including the acquisition of real estate, or other things used for business activity in the zone, and the modernization and expansion of economic and technical infrastructure on its territory. ${ }^{3}$

Table 7 Tax exemptions of companies managing the zones (in million PLN)

\begin{tabular}{|l|c|c|c|c|}
\hline \multicolumn{1}{|c|}{ Zone name } & $\mathbf{2 0 1 2}$ & $\mathbf{2 0 1 3}$ & $\mathbf{2 0 1 4}$ & $\begin{array}{c}\text { Cumulatively at the end } \\
\text { of 2014 }\end{array}$ \\
\hline Kamiennogórska & 0.05 & 0.08 & 0.42 & 2.70 \\
\hline Katowicka & 0.95 & 1.6 & 2.61 & 17.28 \\
\hline Kostrzyńsko-Słubicka & 0.29 & 0.25 & 0.65 & 18.69 \\
\hline Krakowska & 0.2 & 0.15 & 0.06 & 2.32 \\
\hline Legnicka & 1.27 & 0.53 & 1.23 & 11.89 \\
\hline Lódzka & 1.38 & 1.16 & 1.56 & 20.58 \\
\hline Mielecka & 0.41 & 2.17 & 0.6 & 35.20 \\
\hline Pomorska & 0.82 & 0.38 & 0.88 & 14.94 \\
\hline Słupska & 1.91 & 0.72 & 2 & 15.68 \\
\hline Starachowicka & 0.11 & 0.16 & 1.62 & 4.23 \\
\hline Suwalska & 0.04 & 0.01 & 0.28 & 4.19 \\
\hline Tarnobrzeska & 0.08 & 0.01 & 2.2 & 26.54 \\
\hline Wałbrzyska & 15.3 & 7.7 & 0 & 52.73 \\
\hline Warmińsko-Mazurska & 0.21 & 0.02 & 0.03 & 1.79 \\
\hline SUM & 23.02 & 14.94 & 14.14 & 228.76 \\
\hline
\end{tabular}

Source: based on Information on the implementation of special economic zones in 2015.

In year 2014, the companies managing zones benefited from tax exemptions amounting to 14.14 million PLN. As it has no effect on the budget, one can treat this amount as an additional effort in the operation of zones.

3 The ordinance of the Council of Ministers of 12 November 2014 amending the regulation on state aid granted to entrepreneurs operating on the basis of a permit for conducting business activity in Special Economic Zones (Journal of Laws of 2014, item 1755). 
The Katowicka and Tarnobrzeska Zones benefited from the largest tax relief in 2014. The largest zone, the Wałbrzyska Zone, did not benefit from the exemption last year, but, on a cumulative basis, at the end of 2014 it benefited from the highest exemption among all the zones. The company in the zone of Warmia and Mazury gained the lowest tax exemption, cumulatively at the end of 2014 - less than 2 million PLN.

When assessing the economic effects of the specific zones, one should bear in mind that to a large extent they can be determined by the geographic location of areas and the associated level of development of socio-economic infrastructure and the availability of qualified staff. The zones which are among the leading ones when it comes to the number of permits granted, the value of investment and number of jobs created are located in the western, southern and central part of Poland, that is, in areas much more attractive in terms of investment compared with the northern and eastern part of the country.

\section{The DEA method in the evaluation of the effectiveness of the Special Economic Zones}

One can talk about the effectiveness of the company or the decision-making authority when a unit is able to achieve the intended effects with the expenditure established. However, to be able to determine whether a unit is effective or ineffective, it is necessary to determine the appropriate method of measurement and the relevant parameters, i.e. expenditure and results. In the event where they can be easily defined it is worth taking account of the assumptions of the function of production and use the parametric method, which indicates the maximum product that can be obtained with given expenditure. However, in the case of units for which one cannot observe all the combinations of expenditure and results, a nonparametric method should be used. These unites are, inter alia, local government units, schools, hospitals, and also, as described above, the Special Economic Zones where the expenditure may include, inter alia, infrastructure spending, and in the case of the results it is the increase in employment.

The DEA method is a nonparametric method for measuring efficiency. It allows the comparison of the objects in the same sector and the pattern selection (Data Envelopment Analysis) (Ćwikała-Małys \& Nowak, 2009). The main advantage is that it does not require the knowledge of a functional relationship when assessing the effect of multiple input variables on output variables. In this way it facilitates the multi-criteria evaluation, and thus is more flexible compared to parametric methods (Ćwikała-Małys \& Nowak, 2009).

The DEA method examines the so-called DMUs (Decision Making Unit). The relative productivity of the decision-making unit is determined on the basis 
of the results determined by the relationship between input and output variables. The method is based on the determination of the efficiency curve (best practice frontier) determined by the examined units which operate efficiently, and the ones which are below the curve are the inefficient units, and the degree of inefficiency depends on the distance of the unit from the efficiency curve (Nazarko, Komuda, Kuźmicz, Szubzda, \& Urban, 2008).

In assessing effectiveness, one should remember about the division of evaluation areas with regards to the technical aspect, allocation and costs (Ćwikała-Małys $\&$ Nowak, 2009). What is assumed as a measure of technical efficiency is the relationship between the productivity of a given object and the maximum productivity that can be achieved with the same technological conditions. Technical efficiency can be aimed at expenditure or effects. The model focused on expenditure indicates how inefficient units can increase their efficiency by reducing expenditure. However, the DEA models focused on results give the answer to the question: what level of performance would an effective unit achieve if it used all the available expenditure? That is, how one can improve the results with the given expenditure (ĆwikałaMałys \& Nowak, 2009).

Allocative efficiency can be measured when one has the information on expenditure price or results. This measure provides information about whether the used combination of expenditure and results is appropriate from an economic point of view. Cost efficiency is measured by comparing the actual costs incurred with the smallest cost with which given results can be achieved (based on the border function of costs) (Nazarko et al., 2008).

DEA models may differ when it comes to the approach to the scale effect. In the DEA model which assumes the constant economies of scale (model CCR the initials of the names of the creators: Charnes, Cooper, and Rhodes), the relative efficiency of the unit is the same in the case of the orientation towards expenditures and results (effects). The model assuming variable economies of scale (BCC) adopts three basic assumptions. Firstly, all the observed production plans are possible. Secondly, if the production plan is possible, then each plan which uses more expenditure and allows for achieving smaller results is also possible. Thirdly, the convex combination of existing plans is possible. The units are compared to the existing production plans or their convex combinations (ĆwikałaMałys \& Nowak, 2009).

When analysing the effectiveness of Special Economic Zones, to bypass the benefits or disadvantages of scale, we will use the basic DEA model assuming constant economies of scale. It is worth noting here that the unit which is effective with constant economies of scale is also effective in the variable economies of scale. The DEA model assuming constant economies of scale rules out the possibility of the analysis oriented towards expenditures or results (Guzik, 2009). 
The CCR model is described as follows:

$$
E j=\frac{\sum_{r=1}^{R} u_{r} y_{r j}}{\sum_{n=1}^{N} v_{n} x_{n j}},
$$

assuming:

$$
\begin{gathered}
\frac{\sum_{r=1}^{R} u_{r} y_{r j}}{\sum_{n=1}^{N} v_{n} x_{n j}} \leq 1, \\
u_{r} \geq 0, v_{n} \geq 0,
\end{gathered}
$$

where:

$E j$ - object efficiency $j(j=1, \ldots, n)$,

$y_{r j}$ - results stream,

$u_{r}$ - weight corresponding to specific outputs $(r=1, \ldots, \mathrm{R})$,

$x_{n j}$ - expenditure stream,

$v_{n}$ - weight corresponding to specific inputs $(n=1, \ldots, \mathrm{N})$.

The DEA method does not require prior knowledge of weights. For each unit the solution to the issue of linear programming is established where the relation between effects/expenditure is maximized under the given constraints. In this way, the strong sides of the unit are exposed (Nazarko et al., 2008).

To check the effectiveness of fourteen economic zones (DMU) the effects were listed with one another, namely: permits issued, new jobs and capital expenditures incurred by entrepreneurs in the zones. Expenditures include: spending on infrastructure and promotion, tax exemptions of companies managing the zones and the area in hectares.

Table 8 shows that 5 among 14 Special Economic Zones are effective. These include the Kamiennogórska Zone, which in 2014 was characterized by almost the lowest number of the permits issued (7), but at the same time the lowest amount was spent on infrastructure (300 thousand PLN), which represented in 2014 only $0.1 \%$ of all expenditure on infrastructure by SEZ. Another effective zone is the Legnicka Zone. In this zone, the percentage of land development is the lowest (26.6\%), but in 2014 companies operating within it ranked the third place in terms of capital expenditure (almost 832 million PLN), while the high growth rate in terms of new jobs and permits was recorded (compared to 2013), and infrastructure spending remained at a low level. 
Table 8 Effectiveness of Special Economic Zones in Poland in 2014

\begin{tabular}{|l|c|c|}
\hline \multicolumn{1}{|c|}{ Zone name } & Effectiveness & Ranking \\
\hline Kamiennogórska & 1.000 & 1 \\
\hline Katowicka & 0.289 & 14 \\
\hline Kostrzyńsko-Słubicka & 0.558 & 9 \\
\hline Krakowska & 0.924 & 7 \\
\hline Legnicka & 1.000 & 6 \\
\hline Łódzka & 0.972 & 8 \\
\hline Mielecka & 0.700 & 13 \\
\hline Pomorska & 0.343 & 11 \\
\hline Słupska & 0.417 & 12 \\
\hline Starachowicka & 0.392 & 1 \\
\hline Suwalska & 1.000 & 10 \\
\hline Tarnobrzeska & 0.513 & 1 \\
\hline Wałbrzyska & 1.000 & 1 \\
\hline Warmińsko-Mazurska & 1.000 & 1 \\
\hline
\end{tabular}

The third effective zone is the Suwalska Zone which in terms of the area is the smallest, but in 2014 was characterized by the highest growth rate in terms of capital expenditure (+ 415\% compared to the previous year). In this zone spending on infrastructure was minimal, and the increased number of investors could have been associated with promotional costs. The fourth effective zone is the zone of Wałbrzych, which in turn is the largest operating zone in Poland, and thus recorded the highest value in terms of the number of permits issued and capital expenditures, while spending on infrastructure in the zone of Wałbrzych was lower than in the other three zones. The last effective zone is the zone of Warmia-Mazury whose area is developed in almost 70\% and yet the dynamics of the permits issued in 2014 compared to 2013 was high and exceeded 90\%. In this zone in 2014 the smallest amount was spent on promotion.

The three least effective zones are the Pomorska, Katowicka and Starachowicka Zones. The Pomorska Zone was characterized by high promotional spending and tax exemption, and in terms of new jobs and permits issued was behind the smaller zones. The Katowicka Zone is the second largest zone but it is the only area that had the negative value of the acquired investment expenditure due to the withdrawal of the permit of a large investor, and, at the same time, in this zone infrastructure expenditure was the largest. The Starachowicka Zone is a zone in which the smallest number of permits was issued in 2014, and the number of new jobs was lower only in the Słupska Zone which is the smallest zone. In contrast, the companies man- 
aging the zone in 2014 benefited from almost the highest tax exemptions (only the Katowicka Zone received a higher result in this area) in the amount of 1.62 million, which accounts to almost $12 \%$ of all tax exemptions from which companies managing the zones benefited in 2014 .

\section{Conclusions}

The aim of the study was to select the pattern of the zone which operating under the same market conditions can maintain the correct ratio of results to expenditure. As a result of the study 5 zones which in 2014 can be described as effective zones were selected. These zones include the Kamieniogórska, Legnicka, Suwalska, Wałbrzyska and Warmińsko-Mazurska Zones. The Pomorska, Katowicka and Starachowicka Zones were among the areas that are the farthest from the selected patterns. Considering the location of the zone and the result of the analysis one can see that the location of the zone does not affect the degree of efficiency. For example, the Katowicka Zone is located in the south in the Śląskie, Małopolskie and Opolskie voivodeships which are characterized by highly developed socio-economic infrastructure and the availability of qualified personnel, turned out to be the least effective zone and the Suwalska Zone functioning mainly in the Podlaskie in 2014 was the effective zone. Therefore, one can conclude that the effectiveness of the unit is to a large extent about the wise management of available resources.

The DEA analysis indicated results possible to achieve, saving areas and the factors that have the greatest impact on the effectiveness of the zones. These results, although limited in scope, because they apply only to year 2014, show that the Special Economic Zones are diverse in terms of their efficiency of operation. They indicate that the expenditures incurred by the specific zones do not translate into the acquisition of new entrepreneurs, and consequently, the creation of new jobs and investments.

\section{References}

Ćwiąkała-Małys, A., \& Nowak, W. (2009). Sposoby klasyfikacji modeli DEA. Badania Operacyjne i Decyzje, (3), 5-18.

Golik, D., \& Kątnik-Prokop, J. (2014). Funkcjonowanie specjalnych stref ekonomicznych w Polsce. Studia Ekonomiczne, 166, 180-193.

Guzik, B. (2009). Podstawowe modele DEA w badaniu efektywności gospodarczej i społecznej. Poznań: Wydawnictwo Uniwersytetu Ekonomicznego w Poznaniu.

Information on the implementation of special economic zones/Informacja o realizacji specjalnych stref ekonomicznych (2015). Warszawa, retrieved from: https://www.premier.gov.pl/ [accessed: 30.04.2016]. 
Journal of Laws of 2014, item 1755. Ordinance of the Council of Ministers of 12 November 2014 amending the regulation on state aid granted to entrepreneurs operating on the basis of a permit for conducting business activity in special economic zones/Rozporządzenie Rady Ministrów z dnia 12 listopada 2014 r. zmieniające rozporządzenie w sprawie pomocy publicznej udzielanej przedsiębiorcom działającym na podstawie zezwolenia na prowadzenie działalności gospodarczej na terenach specjalnych stref ekonomicznych, Dz.U. z 2014 r., poz. 1755.

Journal of Laws of 2007, No. 42, item 273. The act of 10 October 1994 on special economic zones, consolidated text/Ustawa z dnia 20.10.1994 r. o specjalnych strefach ekonomicznych, tekst jednolity, Dz.U. z 2007 r., nr 42, poz. 273.

Kudełko, J. (2006). Efekty funkcjonowania specjalnych stref ekonomicznych w Polsce jako instrumentu polityki regionalnej. Zeszyty Naukowe AE w Krakowie, (709), 39-57.

Nazarko, J., Komuda, M., Kuźmicz, K., Szubzda, E., \& Urban, J. (2008). Metoda DEA w badaniu efektywności instytucji sektora publicznego na przykładzie szkół wyższych. Badania Operacyjne i Decyzje, (4), 89-105.

Nelec, W., \& Prusek, A. (2006). Funkcje państwa i specjalnych stref ekonomicznych w Polsce w zakresie innowacyjności i konkurencyjności gospodarki. Zeszyty Naukowe AE w Krakowie, (709), 19-37.

\section{Note about the Author}

MAŁgORZATA BŁACHUCIAK - holds a master's degree in economics at the Jagiellonian University, specializing in International Economics and a bachelor's degree in computer science at the Pedagogical University in Kraków. In 2013 she defended her master's thesis in the field of economic development of local government units. She currently works for one of the largest retailers in Poland, dealing with market data, comparing results for the countries of the Visegrad Group and seeking potential for development. Her research interests focus on issues related to economic development and the efficiency of public institutions. 